\section{LJUBIŠA VASOV ${ }^{1}$ BRANIMIR STOJILJKOVIĆ ${ }^{2}$ OLJA ČOKORILO ${ }^{3}$ PETAR MIROSAVLJEVIĆ SLOBODAN GVOZDENOVIĆ}

\author{
1,2,3,4,5 University of Belgrade
} Faculty of Transport and Traffic Engineering Serbia ${ }^{1}$ lj.vasov@sf.bg.ac.rs

\title{
AIRCRAFT NOISE METRICS
}

Abstract: The problem of the aircraft noise is certainly one of the factors that affect not only at the planning of a new airports or expanding of the existing airports, but also at the aviation industry as a whole. In order to mitigate this problem, a series of a different measures are undertaken today, whose effects are finally evaluated by the application of an appropriate indices and the aircraft noise metrics. In this paper, a brief chronological review of the aircraft noise metrics development is shown, as well as their classification according to the different criteria. The analysis of the certain aircraft noise metrics, with the close attention to their interconnections, is accomplished. Additionally for the nowadays frequently used metrics and their advantages and limitations, special attention was given. An overview of the supplemental aircraft noise metrics, which are now proposed and as such can be accepted by the general public, is given.

Key words: aircraft, noise, metrics.

\section{INTRODUCTION}

With the introduction of jet engines in civil aviation, aircraft noise was recognized as environmental issue since from ' $60 \mathrm{~s}$ of the $20^{\text {th }}$ century. Today, this problem still persists and may reach unsustainable levels. This is confirmed by the ICAO (International Civil Aviation Organization) predictions, according to which the number of people who are affected by aircraft noise, with the worst scenario, would be increased from today's 25 million to more than 34 million during the next two decades, in other words $36 \%$ higher than today [1].

Therefore, the issue of aircraft noise is present in all segments of the air transport and traffic system. There are a number of the aircraft noise abatement measures, with the final goal to reduce or limit noise exposure of people living in vicinity of airports. Comprehensive and economically viable way of the available noise abatement measures application at international airports is contained in the ICAO's "Balanced Approach to Aircraft Noise Management" [1]. One of the principal elements of this approach is a reduction of noise at source, and big improvements are achieved in this field. Due to application of high by-pass turbofan engines and improved airframe design, nowadays new types of transport aircraft generate usually up to 100 times lower sound intensity compared to the same category of the older aircraft.

The effects of these measures are described by appropriate indices and the aircraft noise metrics. Establishing of the proper noise metric system is important in prediction of the impact of noise on people, and loudness and annoyance assessment. But, evaluation of human response to noise is compounded because of complexity of human hearing system and human psychology.
Nevertheless, different influential factors on human reaction to noise are usually combined in one comprehensive indicator or single noise metric. There is number of aircraft noise metric that are more or less in using, and almost all of them are based on the decibel scale. Also, different aviation organization, countries, even airports, use different methods and aircraft noise metrics for assessing noise, and there is no common stand for the most complete and best metric that describe aircraft noise exposure.

\section{DEVELOPMENT OF AIRCRAFT NOISE METRICS}

One of the first attempts to characterize aircraft noise is dated back to the late 1950s, when Perceived Noise Level (PNL) is developed by Kryter. PNL is primarily used for assessing the annoyance due to jet aircraft flyover noise, because the commonly used A, as well as $\mathrm{B}$ and $\mathrm{C}$ frequency weighting networks (Figure 1) are unable to emphasize the differences between noisiness of jet aircraft versus propeller aircraft.

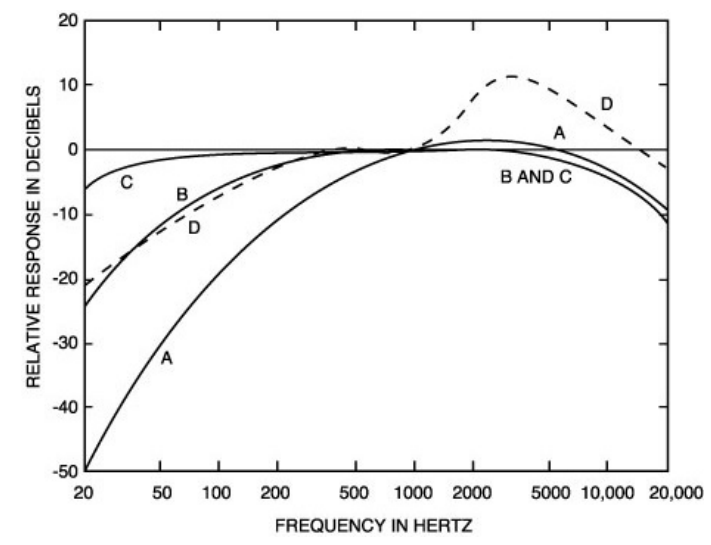

Figure 1 Frequency characteristics of the $A, B, C$ and $D$ weighting networks [2] 
PNL as a single event maximum sound level metric basically is calculated from sound pressure levels measured in octave or one-third octave frequency bands. By reason of a quite complex PNL $\left(L_{P N}\right)$ calculation method the D weighted sound level $\left(L_{D}\right)$ was introduced later as a simpler approximation of PNL, with the following relation between them [3]:

$L_{P N} \approx L_{D}+7( \pm 1 d B)$

Today, D weighted sound level is rarely used for nonbypass or low-bypass turbojet engines that are fitted only in military aircraft. Also, calculation method of PNL does not involve effects of pure tone "swish" that is often present in flyover of turbofan aircraft and duration of a sound. These shortcomings have been overcome later by introducing tone corrected and duration corrected metrics.

During the 1950s the initial assays for estimating community reaction to aircraft noise are led to development of Composite Noise Rating (CNR). An early version of the CNR was designed for any noise source, but the later CNR procedure was shaped for evaluation the aircraft noise exposure and predicting effects of multiple event aircraft operations. The calculation method of CNR $\left(L_{C N R}\right)$ is based on data of aircraft operation (i.e. number of daytime and nighttime takeoffs and landing) and PNL $\left(L_{P N}\right)$ value for the chosen ground location, and the relation for approximate calculation of CNR is [3]:

$L_{C N R} \approx L_{\overline{P N}}+10 \log \left(N_{d}+16.67 N_{n}\right)-12$

where: $L \overline{P N}$ is the average maximum of PNL at a ground location of interest, $N_{d}$ is the number of daytime operations (07:00 to 22:00 hours), $N_{n}$ is the number of nighttime aircraft operations (22:00 to 07:00 hours), 16.67 is weighting factor for nighttime operations and 12 is an arbitrary constant.

$\mathrm{CNR}$ as forerunner to other community noise predictors has few disadvantages that are incorporated through PNL. In the next two decades, from the 1960s to early 1980 s, intense and overall researches in the field of psychoacoustic are brought to "alphabet soup of aircraft noise metric" [4].

Problem of the noisiness assessment of the sounds with prominent discrete frequencies, that are present in flyover of turbofan aircraft, is solved by introducing of Tone Corrected Perceived Noise Level (PNLT). As a PNL, the PNLT is used in assessing the subjective response to single events, and after reviewing the several different procedures of tone correction, PNLT metric procedure was accepted by Federal Aviation Administration (FAA) in 1969.

Actually, there a few methods of the PNLT calculating, but their essence is examination of the band sound pressure levels in a noise spectrum in order to find if the sound level in any frequency bands exceed its adjoining bands. Then, based on numerical difference between successive band sound pressure levels and the process of elimination if the difference does not exceed certain amount, for each of the 24 one-third octave bands tone correction factor $(C)$ is determined (Table $1)$.

Table 1. Tone correction factors [5]

\begin{tabular}{|c|c|c|}
\hline $\begin{array}{l}\text { Frequency } \\
f[\mathrm{~Hz}]\end{array}$ & $\begin{array}{c}\text { Level } \\
\text { difference } \\
F[\mathrm{~dB}]\end{array}$ & $\begin{array}{l}\text { Tone correction } \\
\qquad C[\mathrm{~dB}]\end{array}$ \\
\hline \multirow{3}{*}{$50 \leq f<500$} & $1 \frac{1 / 2 \leq F<3}{4}$ & $F / 3-1 / 2$ \\
\hline & $3 \leq F<20$ & $F / 6$ \\
\hline & $20 \leq F$ & $31 / 3$ \\
\hline \multirow{3}{*}{$500 \leq f<5000$} & $1 \frac{1}{2} \leq F<3$ & $2 F / 3-1$ \\
\hline & $3 \leq F<20$ & $F / 3$ \\
\hline & $20 \leq F$ & $62 / 3$ \\
\hline \multirow{3}{*}{$5000 \leq f<10000$} & $11 / 2 \leq F<3$ & $F / 3-1 / 2$ \\
\hline & $3 \leq F<20$ & $F / 6$ \\
\hline & $20 \leq F$ & $3 \frac{1}{3}$ \\
\hline
\end{tabular}

Because just one tone correction factor may be added to PNL, selection of $C_{\max }$ is needed, and PNLT $\left(L_{T P N}\right)$ is given by:

$L_{T P N}=L_{P N}+C_{\max }$

Certainly, the main disadvantage of PNLT is that it does not account duration of a noise. Influence of noise duration is considered in Sound Exposure Level (SEL), which is actually energy averaged A-weighted sound level over a specified period of time, with the reference of 1 second. Calculation of SEL $\left(L_{A E}\right)$ for temporal sampling is given by relation $\left(\frac{2}{3}\right]$ :

$L_{A E}=10 \log \left(\sum_{i=1}^{n} 10^{\frac{L_{A(i)}}{10}} \Delta t\right)$

where: $L_{A(i)}$ is the instantaneous A-weighted sound level for the $i^{\text {th }}$ sample, $n$ is the number of samples taken during the given period and $\Delta t$ is the time interval between samples. In practice is necessary to take into account sound levels which are within $L_{A \max }$ and $\left(L_{A \max }\right.$ $-10 \mathrm{~dB}$ ) interval, for a noise event such as an aircraft flyover.

Another metric, also A-weighted and energy averaged over specified period of time is Equivalent Continuous Sound Level $\left(L_{A e q}\right)$. This metric as noise descriptor is widespread used for aircraft noise. For continuous time integration $L_{A e q}$ is:

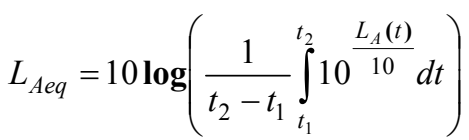

where: $\left(t_{2}-t_{1}\right)$ is the measurement time.

Both, the tone correction and influence of noise duration are included in Effective Perceived Noise Level (EPNL). This is a metric for assesses the noisiness of a single noise event, and EPNL if fundamental metric for aircraft noise certification.

Calculation procedure of EPNL is consisted by few steps with following simplified review [3], [5]: 
- measuring of sound pressure levels of the each 24 one-third octave band with sequence of 0.5 second time interval during the aircraft noise event

- calculation of the PNL value $\left(L_{P N(i)}\right)$ at each $\left(i^{\text {th }}\right) 0.5$ second time interval,

- determination of tone correction factor $\left(C_{i}\right)$ at each $\left(i^{\text {th }}\right) 0.5$ second time interval,

- computation of PNLT value $\left(L_{T P N(i)}\right)$ at each $\left(i^{\text {th }}\right) 0.5$ second time interval according to:

$L_{T P N(i)}=L_{P N(i)}+C_{i}$

- identification of the PNLT maximum $\left(L_{T P N m a x}\right)$, and

- calculation of EPNL $\left(L_{E P N}\right)$ according to:

$L_{E P N}=10 \log \left[\sum_{i=0}^{n} 10^{\frac{L_{T P N(i)}}{10}}\right]-13$

where: constant $-13 \mathrm{~dB}$ is relating the 0.5 second interval to the 10 seconds reference duration, i.e. $10 \log (0.5 / 10)=-13$, and $n$ is the number of time samples when PNLT $\left(L_{T P N(i)}\right)$ is within interval from $L_{\text {TPNmax }}$ to $\left(L_{\text {TPNmax }}-10 \mathrm{~dB}\right)$.

In a number of cases, for EPNL estimation by the SEL can be used according to following approximate relation [3]:

$L_{E P N} \approx L_{A E}+4( \pm 3 d B)$

Today, EPNL as a single number evaluator is widely accepted as basic metric for certification of subsonic jet airplanes, propeller-driven airplanes over $8618 \mathrm{~kg}$ and helicopters over $3175 \mathrm{~kg}$. For propeller-driven airplanes below $8618 \mathrm{~kg}$ noise evaluation measure is maximum A-weighted sound level, and for helicopters below $3175 \mathrm{~kg}$ noise measure is SEL.

During the 1960s and 1970s have been developed a number of multiple event metrics, based on previously described single event metrics. As improvement of CNR, on the mid of 1960s was introduced Noise Exposure Forecast (NEF). Like the CNR, basic purpose of NEF was estimation of community reaction to the aircraft noise and there is strong correlation [3] between $\mathrm{CNR}\left(L_{C N R}\right)$ and $\operatorname{NEF}\left(L_{N E F}\right)$ :

$L_{N E F} \approx L_{C N R}+70$

Calculation of NEF is based on EPNL and data of aircraft operation (i.e. number of daytime and nighttime takeoffs and landing) for different classes of aircraft:

$$
L_{N E F(i, j)}=L_{E P N(i, j)}+10 \log \left(N_{d(i, j)}+16.67 N_{n(i, j)}\right)-88
$$

where: $i$ is the aircraft class, $j$ is flight path, $L_{N E F(i, j)}$ is the NEF for $i^{\text {th }}$ aircraft class flying along the $j^{\text {th }}$ flight path, $L_{E P N(i, j)}$ is the EPNL at a given ground location generated by $i^{\text {th }}$ aircraft class on the $j^{\text {th }}$ flight path, $N_{d(i, j)}$ and $N_{n(i, j)}$ number of $(d)$ day (07:00 to 22:00) and $(n)$ night $(22: 00$ to $07: 00)$ operation of the $i^{\text {th }}$ aircraft class on the $j^{\text {th }}$ flight path, 16.67 is weighting factor for nighttime operations and 88 is an constant.
Then the overall value of the NEF $\left(L_{N E F}\right)$ at a given location is the sum of $L_{N E F(i, j)}$ by the aircraft class ( $i$ ) and flight path $(j)$ :

$$
L_{N E F}=10 \log \left(\sum_{i=1}^{n} \sum_{j=1}^{m} 10^{\frac{L_{N E F(i, j)}}{10}}\right)
$$

Where: $n$ is the number of aircraft class and $m$ is the number of flight paths.

Determined by comprehensive interviews the acceptable NEF values were (6)ry helpful as guidelines for proper land use planning and zoning in vicinity to the airports. Numerous of multiple event aircraft noise metrics was developed during the 1907s with basic purpose of land zoning and regulation. For example, one of them is Community Noise Equivalent Level (CNEL) based on A-weighted sound level and developed in the State of California.

CNEL $\left(L_{d e n}^{*}\right)$ is a 24 hour noise rating metric that includes adjustment factors for evening and nighttime periods, and it is introduced as simplified alternative to the NEF system [6]:

$L_{d e n}^{*} \approx L_{N E F}+35$

The calculation method is based on hourly noise levels [3]:

$$
L_{d e n}^{*}=10 \lg \left[\frac{1}{24}\left(\sum_{i=1}^{12} 10^{\frac{L_{h d(i)}}{10}}+3 \sum_{j=1}^{(8)} 10^{\frac{L_{h e(j)}}{10}}+10 \sum_{k=1}^{9} 10^{\frac{L_{h n(k)}}{10}}\right)\right]
$$

where: $L_{h d(i)}$ is hourly noise level for daytime $(07: 00 \div 19: 00), L_{h e(j)}$ is hourly noise level for evening $(19: 00 \div 22: 00)$ and $L_{h n(k)}$ is hourly noise level for nighttime period $(22: 00 \div 07: 00)$. Also CNEL can be calculated on yearly basis in order to provide guidelines for compatible land using.

Today, CNR and NEF are rarely used and have been replaced by Day-Night Average Sound Level (DNL). Like CNEL, this DNL $\left(L_{d n}\right)$ metric is based on Aweighted sound level over 24 hours, and there is highly correlation between them:

$$
L_{d n} \approx L_{d e n}^{*}
$$

DNL as a single number noise descriptor includes both: the sound levels and number of noise events. The characteristics of sound are measured with averaged Aweighted sound level during the given time period, and DNL metric is improved by addition of adjustment factor for the nighttime noise events.

Calculation of DNL can be accomplished by several methods, and one of them is continuous time integration [3]:

$$
L_{d n}=10 \log \left[\frac{1}{86400}\left(\int_{07: 00}^{22: 00} 10^{\frac{L_{A}(t)}{10}} d t+\int_{22: 00}^{07: 00} 10^{\frac{L_{A}(t)+10}{10}} d t\right)\right]
$$


where: $L_{A}$ is instantaneous A-weighted sound level, 07:00 to $22: 00$ is the daytime interval, $22: 00$ to $07: 00$ is the nighttime interval and 86400 is the number of seconds in 24 hours.

Based on daily calculation of DNL, it can be computed as a Yearly Day-Night Average Sound Level YDNL $\left(L_{d n y}\right)$ :

$L_{d n y}=10 \log \frac{1}{365} \sum_{i=1}^{365} 10^{\frac{L_{d n(i)}}{10}}$

where: $L_{d n(i)}$ is the daily DNL for the $i^{\text {th }}$ day of the year. By the YDNL, it is possible to estimate the long term aircraft noise impact and determinate the cumulative noise exposure around the airport. DNL is one of the measures for community noise exposure recommended by many agencies, and it is used by FAA as primary measure in describing noise around the airport.

Certainly, with DNL the list of present aircraft noise metric is not completed. That was "just one spoon of alphabet soup of aircraft noise metrics" and there is no consensus, which one is most proper and comprehensive.

\section{COMMONLY USED AIRCRAFT NOISE METRICS}

About two decades ago list of employed aircraft noise metrics was very diverse between countries. Some of them have used somewhat unusual aircraft noise metrics, but in time situation in this area is slightly changing.

There is few examples of European countries [7]: until 1990 in UK was used the Noise and Number Index (NNI) when it is replaced by $L_{\text {Aeq }}$, until February 2003 the Netherlands was used the Kosten Index $(K e)$ based on $L_{\text {Amax }}$, when it is replaced by $L_{d e n}$, in France Psophic Index (IP) based on PNL scale was used the until 2002 when it is replaced by $L_{d e n}$, etc.

In European Community, problem of aircraft noise metrics and traffic noise metrics at all, is clarified by Environmental Noise Directive 2002/49/EC of the European Parliament [8].

This Directive harmonizes previous situation, and requires from all Member States to use Day-EveningNight level $\left(L_{d e n}\right)$ for 24 hour period and night level $\left(L_{\text {night }}\right)$ metrics, for purpose of environmental noise levels reporting and mapping. The $L_{d e n}$ is defined by following relation [8]:

$L_{\text {den }}=10 \lg \frac{1}{24}\left(12 \cdot 10^{\frac{L_{\text {day }}}{10}}+4 \cdot 10^{\frac{L_{\text {evening }}+5}{10}}+8 \cdot 10^{\frac{L_{\text {night }}+10}{10}}\right)$

where: $L_{\text {day }}, L_{\text {evening }}, L_{\text {night }}$ are A-weighted long-term average sound level over the day, evening, night period of a year.

Period of 24 hours is divided in three different intervals: 12 hours for day, 4 hours for evening and 8

hours for night. The start of the day may be chosen by the Member States, and a 07:00 hour is default start time of the day.

Day-Evening-Night level $\left(L_{d e n}\right)$ by content is very similar with DNL $\left(L_{d n}\right)$ and CNEL $\left(L^{*}{ }_{d e n}\right)$, but there is certain difference between them due to different duration and weighting for the evening and night period.

However, 2002/49/EC requirement does not imply suspension and exclusion of all other aircraft noise metric in any Member State. There are many examples of using additional indicators and list of commonly used aircraft noise metrics in some of worldwide countries is shown in following (Table 2).

Table 2. Commonly used aircraft noise metrics

\begin{tabular}{|c|c|}
\hline Country & Aircraft Noise Metric \\
\hline Australia & Australian NEF (ANEF), $\mathrm{N}_{70}$ \\
\hline Austria & $L_{\text {den }}, L_{\text {night }}$ \\
\hline Belgium & $\begin{array}{l}\text { ago: Psophic Index (IP), now: DNL, } \\
\text { SEL }\end{array}$ \\
\hline Canada & $\mathrm{NEF}$ \\
\hline Cyprus & $L_{\text {den }}, L_{\text {night }}$ \\
\hline Denmark & $L_{\text {den }}, L_{\text {night }}$ \\
\hline Estonia & $L_{\text {den }}, L_{\text {night }}, L_{\text {de }}, L_{\text {Aeq }}$ \\
\hline Finland & $L_{d e n}, L_{n i g h t}, L_{A e q}$ \\
\hline France & $\begin{array}{l}\text { ago: Psophic Index (IP), now: } L_{d e n} \text {, } \\
L_{\text {night }}\end{array}$ \\
\hline Germany & ago: Störindex " $Q$ ", now: $L_{\text {den }}, L_{\text {night }}$ \\
\hline Greece & ago: NEF, now: $L_{d e n}, L_{\text {night }}$ \\
\hline Hong Kong & $\mathrm{NEF}$ \\
\hline Ireland & $L_{\text {den }}, L_{\text {night }}, L_{\text {Aeq }}, L_{\text {Amax }}$ \\
\hline Italy & $L_{V A}$ equivalent of $L_{e q}$ \\
\hline Japan & $\begin{array}{l}\text { ago: } \mathrm{WECPNL}^{1} \text {, now: } L_{e q} \text { based } \\
\text { metric }\end{array}$ \\
\hline Lithuania & $L_{\text {den }}, L_{\text {night }}$ \\
\hline Luxemburg & ago: Störindex " $Q$ ", now: $L_{\text {den }}, L_{\text {night }}$ \\
\hline Netherlands & $\begin{array}{l}\text { ago: Kosten Index, now: } L_{\text {den }}, L_{\text {night }} \text {, } \\
L_{\text {Aeq }}\end{array}$ \\
\hline New Zealand & DNL \\
\hline Norway & Equivalent Aircraft Noise (EFN) \\
\hline Portugal & $L_{\text {den }}, L_{\text {night }}$ \\
\hline Romania & $L_{\text {den }}, L_{\text {night }}$ \\
\hline Slovakia & $L_{\text {den }}, L_{\text {night }}$ \\
\hline Slovenia & $L_{\text {den }}, L_{\text {night }}$ \\
\hline Spain & ago: NEF , now: $L_{d e n}, L_{\text {night }}$ \\
\hline Sweden & $\begin{array}{l}\text { ago: } \mathrm{FBN} \text {, now: } L_{\text {den }}, L_{\text {night }}, L_{\text {day }} \text {, } \\
L_{\text {evening }}\end{array}$ \\
\hline Switzerland & hourly $L_{e q}$ \\
\hline UK & ago: NNI , now: $L_{\text {den }}, L_{\text {night }}, L_{\text {Aeq }}$ \\
\hline Ukraine & $L_{A e q}$ \\
\hline US & DNL, CNEL \\
\hline
\end{tabular}


It is very important to emphasize that Environmental Noise Directive 2002/49/EC foresees using of supplementary noise indicators in some cases, such as [8]:

- noise source operates only small proportion of time,

- the average number of noise events is very low,

- the low frequency content of noise is strong,

- needs for extra protection at the weekend, or specific part of year, or day period, or evening period,

- the noise has an impulsive character, etc.

Previously mentioned issues are subject of discussion how to improve the ability of the aircraft noise impacts prediction and the public understanding of the aircraft noise metrics.

\section{AIRCRAFT NOISE METRICS CLASSIFICATION}

Previously mentioned aircraft noise metrics by content can be classified in several groups, based on different criteria. At the aircraft noise metric definition level, there are a several basic factors that determine noise metric character, as:

- the sound level,

- the frequency or pitch of the sound,

- the duration of the sound,

- the number of noise events,

- the time of day (day-evening-night), etc.

Many of previously described aircraft noise metrics aggregate these factors in one single value, and one given metric at the same time can belong on different classes of the aircraft noise metrics. One of commonly used classification separate those according to the criteria of single and multiple events, and the criteria of energy dose and cumulative time metrics (Table 3 ).

Table 3. Aircraft noise metrics classification

\begin{tabular}{ll}
\hline Criteria & Aircraft Noise Metrics \\
\hline \multirow{3}{*}{$\begin{array}{l}\text { Single event maximum } \\
\text { sound levels }\end{array}$} & A-weighted sound level \\
\cline { 2 - 2 } & D-weighted sound level \\
\cline { 2 - 2 } $\begin{array}{l}\text { Single event energy } \\
\text { dose metrics }\end{array}$ & PNL \\
\hline \multirow{4}{*}{$\begin{array}{l}\text { Cumulative energy } \\
\text { average metrics }\end{array}$} & EPNL \\
\cline { 2 - 2 } & SEL \\
\cline { 2 - 2 } & DNEF \\
\cline { 2 - 2 } & NEF \\
\cline { 2 - 2 } & WECPNL \\
\cline { 2 - 2 } $\begin{array}{l}\text { Cumulative time } \\
\text { metrics }\end{array}$ & NNI \\
\hline
\end{tabular}

In addition to these classes of aircraft noise metric, there is another one with so called supplementary noise metrics, as:

- Statistical Sound Level $\left(L_{x}\right)$,

- Number Above $\left(\mathrm{N}_{70}\right)$,

- Person Event Index (PEI), etc.

These supplementary noise metrics are noise descriptors with the basic purpose to improve public understanding of the manner in which aircraft noise is characterized [4].

\section{SUPPLEMENTARY AIRCRAFT NOISE METRICS}

Today conventional aircraft noise metric are more often under criticism, because there are some limitations of cumulative energy average metrics, such as commonly used $L_{d e n}$ or DNL metrics. These limitations are connected with the concept itself of the DNL and $L_{d e n}$ or any other averaged aircraft noise metric definition. When using DNL to explain noise exposure to the average citizen, a more typical response is "I don't hear averages, I hear individual airplanes" [9].

There are a number of reasons of misunderstanding and distrust by the public, and most important are:

- the quantity of noise exposure expressed in 24 hour cumulative time weighted average level is outside of common experience of noise, and cannot be directly experienced by observation in the same sense as the maximum sound level of a single noise event [4], and

- by aggregating the different elements of the sound into one single aircraft noise metric, identity of the individual factors is lost, that perturbs understanding of influence of specific elements (maximum levels, frequency, duration, number of noise events, etc.).

In addition to this, logarithmic relations and manipulation in almost all aircraft noise metric are indirect and non-intuitive for wider audiences. For these reasons the certain set of noise indicators have been considered as supplement to the usual conventional noise metrics. Some of the supplemental noise metrics that have been useful to the analysis of aircraft noise exposure are:

- Time Above (TA): time of noise exposure during the observation period at given locations, above some preselected threshold of A-weighted sound level [3],

- Statistical Sound Level $\left(L_{x}\right)$ : the A-weighted sound level exceeded for $x \%$ of the measurement period [7] at given location (common used are $L_{10}, L_{50}$ and $L_{90}$ ),

- Number of events Above a threshold level (NA): the number of aircraft noise events above the specified noise level for a given location and during a specific period of time, (in Australia is widely 
used $\mathrm{N}_{70}$, i.e. the number of aircraft noise events above 70dBA),

- Person Event Index (PEI), the total number of instances where an individual is exposed to an aircraft noise event above a specified noise level over a given period [7]:

$\operatorname{PEI}(x)=\sum P_{N} \cdot N$

where: $x$ is single event threshold noise level in dBA, $P_{N}$ is number of persons exposed to $N$ noise events with noise level greater then $x$ (the PEI is summed between $N_{\min }$ and $N_{\max }$ ).

These noise descriptors give answers to simple questions, as: "how long will it be this noisy during the day" or "how many noisy aircraft can be heard throughout the day". By treating aircraft noise through the noise exposure time or total number in series of the single noise events rather than as calculated cumulative acoustic averages, a more understandable mental picture of noise exposure is enabled.

It is important to emphasize that supplemental aircraft noise metrics are not replacement for energy average metrics. Also, these noise metrics can not increase accuracy of noise impact prediction, but may improve a public understanding of current noise environment and changes of the aircraft noise impact.

\section{CONCLUSION}

Today, different aircraft noise metrics are in using, and many of these are mutually similar and based on same concept of aggregation of the acoustics and the psychoacoustics factors in to one single noise indicator. There is no common stand for the most complete noise metric that describes aircraft noise exposure. Deficiency of a communication language in relation to aircraft noise with the general public is stumbling block to the effective noise management. Overcoming of this problem can be achieved by using the other supplemental aircraft noise metrics. By using of the supplementary aircraft noise metrics and descriptive discussion of the noise impacts, the confusing and potentially misleading can be avoided.

\section{REFERENCES}

[1] Lj. Vasov, S. Gvozdenović, O. Čokorilo, P. Mirosavljević, B. Stojiljković, "Elements of Aircraft Noise Management", $23^{\text {rd }}$ National Conference \& $4^{\text {th }}$ International Conference NOISE AND VIBRATION, Niš, 17-19 October, 2012.

[2] Portland International Jetport Noise Exposure Map, Appendix A: Noise Metric and Acoustic Terminology, HMMH Report No. 298410, March, 2004.

[3] R. Benett, K. Pearsons, Handbook of Aircraft Noise Metrics, NASA CR-3406, March, 1981.

[4] V. Mestre, P. Schomer, S. Fidell, B. Berry, "Technical Support for Day/Night Average Sound Level (DNL) Replacement Metric Research", DOT/FAA/AEE/2011-2, June, 2011.

[5] ICAO Annex 16, Volume 1, Aircraft Noise, Appendix 2: Evaluation Method for Noise Certification of Subsonic Jet Airplanes, Propeller Driven Airplanes Over 8618kg, Helicopters, Sixth Edition, July, 2011.

[6] B. Truax, R. Schafer, Handbook for Acoustic Ecology, Cambridge Street Publishing, Second Edition 1999, http://www.sfu.ca/sonic-studio/handbook/index.html

[7] K. Jones, R. Cadoux, Metrics for Aircraft Noise, CAA Environmental Research and Consultancy Department, ERCD Report 0904, London, January 2009.

[8] Directive 2002/49/EC of the European Parliament and of the Council, June 2002.

[9] Improving Aviation Noise Planning, Analysis and Public Communication with Supplemental Metrics, Department of DNWG, Washington, December 2009

\section{VELIČINE ZA OCENJIVANJE BUKE VAZDUHOPLOVA Ljubiša Vasov, Branimir Stojiljković, Olja Čokorilo, Petar Mirosavljević, Slobodan Gvozdenović}

Rezime: Problem buke vazduhoplova je svakako jedan od faktora koji utiče ne samo na planiranje novih i razvoj postojećih aerodroma, već i na vazduhoplovnu industriju u celini. U cilju ublažavanja ovog problema danas se preduzima čitav niz različitih mera, čiji se efekti primene konačno ocenjuju preko odgovarajućih indeksa $i$ veličina za ocenjivanje buke vazduhoplova. U ovom radu je prikazan kratak hronološki pregled razvoja veličina za ocenu buke vazduhoplova, kao i njihova klasifikaciju po različitim kriterijumima. Izvršena je analiza pojedinih veličina za ocenu buke vazduhoplova, sa bližim osvrtom na njihove međusobne veze. Pored toga, posebna pažnja je posvećena danas često korišćenim veličinama, njihovim prednostima i ograničenjima. Dat je prikaz i značenje dopunskih i alternativnih veličina za ocenjivanje buke vazduhoplova, koje se danas predlažu i kao takve mogu biti prihvaćene u široj javnosti.

Ključne reči: vazduhoplov, veličine za ocenu buke, klasifikacija. 